\title{
KEMAMPUAN MENULIS AKADEMIK GURU MATA PELAJARAN NON-BAHASA DI JAWA BARAT
}

\author{
Riswanda Setiadi \\ FPBS Universitas Pendidikan Indonesia \\ email: riswandasetiadi@gmail.com
}

\begin{abstract}
Abstrak
Penelitian ini bertujuan: (a) mengukur tingkat kemampuan guru dalam menulis akademik, (b) menganalisis kesalahan guru dalam hasil tes tulisan akademik, dan (c) mengidentifikasi faktor penyebab kesulitan guru dalam mengembangkan kemampuan menulis akademik. Subjek penelitian adalah 126 guru mata pelajaran non-bahasa yang berasal dari 14 kabupaten/kota di Jawa Barat, yang telah mengikuti program sertifikasi guru. Hasil penelitian menunjukkan bahwa secara keseluruhan, skor rata-rata tulisan akademik yang dicapai oleh guru adalah 57,2 dari skor total 100. Merujuk kepada skala penilaian tulisan akademik, skor rata-rata ini menunjukkan kategori "cukup baik". Pengalaman menulis, pelatihan, dan budaya akademik merupakan faktor penting yang berkontribusi terhadap kemampuan guru dalam menulis karya akademik.
\end{abstract}

Kata kunci: menulis akademik, guru non-bahasa, pengembangan profesional

\section{THE ACADEMIC WRITING SKILLS OF NON-LANGUAGE TEACHERS IN WEST JAVA PROVINCE}

\begin{abstract}
This study aims to: (a) assess the academic writing skills of non-language teachers, (b) analyze mistakes in their academic writing test results, and (c) identify factors causing the difficulties they encounter in developing their academic writing skills. The subjects were 126 non-language teachers who had participated in the teacher certification program from 14 regencies/cities in West Java Province. The findings show that on the whole their academic writing mean score is 57.2 of a total score of 100 . Referring to an academic writing assessment scale, the mean score is fairly good. Writing experiences, training, and academic atmosphere are important factors that have contributions to teachers' academic writing skills.
\end{abstract}

Keywords: academic writing, non-language teachers, professional development

\section{PENDAHULUAN}

Sejak tahun 2005 pemerintah Indonesia telah memiliki komitmen kuat untuk memperbaiki kedudukan guru dan meningkatkan kompetensi mereka. Komitmen ini diwujudkan dengan pemberlakuan Undang-Undang No. 14 tentang Guru dan Dosen. Di dalam UU ini disebutkan bahwa "guru adalah pendidik profesional dengan tugas utama mendidik, mengajar, membimbing, mengarahkan, melatih, menilai dan mengevaluasi peserta didik pada pendidikan anak usia dini jalur pendidikan formal, pendidikan dasar, dan pendidikan menengah." Dengan memperhatikan amanat undang-undang, maka profesi guru sangat bermakna strategis. Namun demikian, posisi strategi dari profesi guru ini memiliki implikasi lebih jauh, yaitu perluasan tugas dan kewa- 
jiban guru dalam menjalankan kegiatankegiatan profesi mereka. Dalam hal ini, para guru dituntut untuk melaksanakan proses pengembangan profesional yang berkelanjutan. Salah satu tuntutan itu adalah peningkatkan kemampuan menulis untuk tujuan publikasi ilmiah.

Merujuk kepada Peraturan Menteri PAN dan RB No. 16/2009 tentang Jabatan Fungsional Guru dan Angka Kreditnya, guru dituntut untuk mampu menyajikan bentuk-bentuk tulisan ilmiah dalam rangka pengembangan keprofesian berkelanjutan, yaitu: (1) presentasi pada forum ilmiah, (2) melaksanakan publikasi Ilmiah hasil penelitian atau gagasan ilmu pada bidang pendidikan formal, dan (3) melaksanakan publikasi buku teks pelajaran, buku pengayaan, dan pedoman guru. Memperhatikan kebijakan ini, maka tidak dapat dipungkiri bahwa para guru harus membangun budaya akademik yang selama ini tidak ada atau tidak mendukung kreativitas mereka dalam kegiatan menulis akademik. Selanjutnya, kebijakan ini tidak hanya dimaksudkan agar para guru mampu memenuhi angka kredit untuk kenaikan pangkat, tetapi juga mampu menciptakan budaya literat dalam pengembangan karir mereka dan menjadikan sekolah sebagai masyarakat intelektual yang penuh dengan kegiatankegiatan akademik dan ilmiah.

Akhir-akhir ini, para guru dilibatkan dalam berbagai kegiatan akademik, terutama pelatihan kinerja akademik. Salah satu program pelatihan untuk meningkatkan kinerja guru ini adalah sertifikasi guru. Program sertifikasi guru yang telah dimulai pada 2007 merupakan satu upaya pemberdayaan guru dan ditujukan untuk (1) menentukan kelayakan guru dalam melaksanakan tugas sebagai pendidik profesional, (2) meningkatkan proses dan hasil pembelajaran, (3) meningkatkan kesejahteraan guru, dan (4) meningkatkan martabat guru dalam rangka mewujudkan pendidikan nasional yang bermutu
(Depdiknas, 2008). Dalam program sertifikasi ini, menulis akademik merupakan satu kegiatan utama yang ditujukan untuk mendorong para guru tetap menulis untuk berbagai kepentingan akademik.

Salah satu keterampilan yang harus dikuasai dengan baik oleh para guru untuk menunjukkan jati diri profesional mereka sebagai masyarakat akademik adalah keterampilan menulis akademik, baik untuk tujuan pribadi maupun kepentingan profesional mereka. Tidak dapat dipungkiri bahwa kemampuan menulis akademik di kalangan guru masih belum memuaskan. Apabila kita hanya melihat kondisi dan budaya sekolah yang tidak mendukung guru untuk meningkatkan keterampilan ini, maka sangat sulit dipahami mengapa para guru yang bekerja sehari-hari di lingkungan akademik tidak mampu menulis karya akademik dengan baik. Kondisi seperti ini menunjukkan bahwa seolah-olah sekolah tidak dihuni oleh masyarakat literat, yakni masyarakat yang disibukkan dengan kegiatan membaca dan menulis. Sementara itu, banyak pihak hanya mengklaim bahwa para guru tidak mampu menulis akademik, terutama menulis karya ilmiah untuk kepentingan kenaikan pangkat mereka, tanpa adanya upaya untuk menelusuri faktor-faktor yang menyebabkan masalah tersebut.

Sebenarnya kemampuan menulis akademik dapat membantu para guru mengungkapkan gagasan dan pandangan berkaitan dengan berbagai hal. Bahkan mereka tidak hanya akan mengenal kaidah-kaidah dan gaya penulisan tetapi juga mampu mengembangkan pemahaman tentang proses pembelajaran. Lebih dari itu, mereka akan menjadi model bagi para siswa dan menjadikan sekolah atau kelas sebagai satu lingkungan literat. Namun demikian, kondisi ideal seperti ini tampak sulit untuk dicapai karena berbagai faktor. Berdasarkan latar belakang di atas, penelitian ini akan berusaha mengidentifikasi sejumlah kesulitan yang 
menghambat para guru dalam membuat tulisan akademik. Fokus utama penelitian ini adalah analisis kesulitan yang dihadapi oleh para guru dalam aspek pengetahuan bahasa dan kaidah-kaidah kebahasaan yang berlaku dalam bahasa Indonesia. Selama ini, belum ada penelitian yang cukup komprehensif mengkaji masalah tersebut. Berdasarkan latar belakang di atas, maka penelitian ini ditujukan untuk mengukur tingkat kemampuan guru dalam menulis akademik, menganalisis kesalahan-kesalahan yang dilakukan oleh guru dalam hasil tes tulisan akademik mereka dan mengidentifikasi faktor-faktor yang menyebabkan kesulitan bagi guru dalam mengembangkan kemampuan menulis akademik.

\section{METODE}

Penelitian ini menggunakan metode deskriptif untuk memaparkan kondisi terkini yang berkaitan dengan kemampuan guru mata pelajaran non-bahasa dalam menulis akademik. Paparan difokuskan pada kemampuan dan pengetahuan bahasa, pengalaman menulis, pelatihan dan pengaruh budaya akademik yang dihadapi oleh para guru non-bahasa dalam mengembangkan kemampuan menulis akademik. Untuk mengumpulkan data tentang fokus masalah ini, terlebih dahulu peneliti memilih teknik pengambilan sampel dan menentukan jumlah sampel yang diperlukan. Pada akhirnya, sampel penelitian dipilih di antara para guru yang mengajar berbagai mata pelajaran selain mata pelajaran bahasa, di tingkat SMP dan SMA di Jawa Barat, dan pengambilan sampel ini didasarkan pada data tentang peserta sertifikasi guru yang diperoleh dari Panitia Sertifikasi Guru dalam Jabatan Universitas Pendidikan Indonesia. Karena populasi guru non-bahasa di Jawa Barat sangat besar dan domisili mereka tersebar di banyak kabupaten/kota, maka sampel penelitian diambil menurut area sampling technique dan purposive sampling technique.
Area sampling technique digunakan untuk mengambil sampel dari daerahdaerah tertentu yang mengirimkan para peserta sertifikasi guru, sedangkan purposive sampling technique diterapkan untuk memilih sejumlah mata pelajaran yang diajarkan di tingkat SMP dan SMA. Dalam hal ini, purposive sampling technique dipilih karena peneliti sengaja memilih para guru yang mengajar mata pelajaran sesuai dengan kebutuhan penelitian. Mata pelajaran yang dipilih adalah Biologi, Geografi, Matematika, Seni Budaya, dan Pendidikan Kewarganegaraan (PKn). Kelima mata pelajaran ini memiliki jumlah guru yang lebih besar dibanding dengan mata pelajaran lain yang disertakan dalam program sertifikasi guru. Meskipun kedua teknik pengambilan sampel tersebut ditentukan oleh peneliti, namun keterlibatan para guru sebagai sampel dalam penelitian ini bersifat sukarela. Dalam penelitianini sebanyak 125 guru dari berbagai mata pelajaran telah dilibatkan dan mereka berasal dari 14 kota/kabupaten di Jawa Barat, yaitu Kota Bekasi, Kota Bandung, Kota Cirebon, Kota Tasikmalaya, Kota Bogor, Kota Banjar, Kabupaten Bandung, Kabupaten Garut, Kabupaten Indramayu, Kabupaten Cianjur, Kabupaten Kuningan, Kabupaten Cirebon, Kabupaten Bandung Barat, dan Kabupaten Tasikmalaya. Sebagai informasi tambahan, para guru yang terlibat dalam penelitian ini adalah mereka yang telah mengikuti sertifikasi guru melalui program Pendidikan dan Latihan Profesi Guru (PLPG) pada tahun 2013.

Sesuai dengan tujuan penelitian ini, ada dua instrumen yang dirancang dan digunakan untuk mengumpulkan data dari sampel penelitian. Kedua instrumen itu adalah tes essai menulis akademik dan angkat. Tes essai dimaksudkan untuk mengumpulkan data tentang tulisan akademik yang ditulis oleh para guru. Essai yang ditulis oleh para guru dinilai menurut instrumen yang dikembangkan 
oleh Brown (2007: 211) dengan fokus pada enam kriteria atau komponen penting yang harus dipenuhi dalam sebuah tulisan akademik: content, organization, discourse, syntax, vocabulary dan mechanics. Sementara itu, angket telah digunakan untuk mengumpulkan informasi tentang tujuan menulis, frekuensi menulis, lingkungan kerja, budaya akademik dan kebiasan menulis guru.

Selanjutnya, data yang dihasilkan dalam penelitian ini adalah data kuantitatif yang berasal dari tes esai dan data kualitatif yang bersumber dari angket. Meskipun data kuantitatif dihasilkan dalam penelitian ini, namun pengolahan dan analisisnya hanya menggunakan teknik statistik sederhana, yakni statistik deskriptif. Sementara itu, data kualitatif akan diolah menurut frekuensi respon atau jawaban yang diberikan oleh sampel penelitian. Untuk mempermudah proses scoring, Brown (2007) juga menyarankan penggunaan skala berikut ini. Bergantung pada tingkat kesulitan yang dihadapi oleh seorang penulis ketika menyusun sebuah tulisan akademik, maka skor untuk setiap kriteria berbeda-beda. Tabel 1 menunjukkan instrumen penskoran tulisan akademik yang digunakan dalam penelitian.

Tabel 1. Instrumen Penskoran Tulisan Akademik

\begin{tabular}{cll}
\hline No & \multicolumn{1}{c}{ Kriteria } & \multicolumn{1}{c}{ Skor } \\
\hline 1 & Content & $0-24$ \\
2 & Organization & $0-20$ \\
3 & Discourse & $0-20$ \\
4 & Syntax & $0-12$ \\
5 & Vocabulary & $0-12$ \\
6 & Mechanics & $0-12$ \\
\hline & Total & 100 \\
\hline
\end{tabular}

Jumlah skor untuk setiap komponen berbeda karena setiap komponen diyakini memiliki tingkat kesulitan tersendiri. Komponen 'content' memiliki skor ter- tinggi karena komponen ini melibatkan sejumlah sub-kategori yang memang sulit untuk dipenuhi dalam proses menulis. Untuk menentukan kualitas tulisan akademik, maka setiap skor yang diraih oleh sampel penelitian dikonversikan ke dalam bentuk skala seperti terlihat dalam Tabel 2.

Tabel 2. Skala Penilaian Kualitas Tulisan Akademik

\begin{tabular}{cl}
\hline Rentang skor & Kualitas \\
\hline $85-100$ & Sangat baik \\
$70-84$ & Baik \\
$55-69$ & Cukup \\
$40-54$ & Kurang \\
\hline
\end{tabular}

\section{HASIL DAN PEMBAHASAN}

Kemampuan Menulis Akademik Guru

Sebagaimana disebutkan di atas, instrument tes menulis digunakan untuk menghasilkan sebuah karya tulis dalam bentuk esai. Selanjutnya, setiap esai ini dinilai menurut organization, content, discourse, syntax, vocabulary dan mechanics sebagaimana dikembangkan oleh Douglas Brown (2007). Dalam penelitian ini, definisi esai yang diadopsi adalah, "An essay is a piece of writing several paragraphs long instead of just one or two paragraphs. It is written about one topic, just as a paragraph is" (Oshima \& Hogue, 1996: 100). Jadi, esai adalah satu bentuk tulisan yang berisi beberapa paragraph dan ditulis tentang sebuah topik. Tetapi esai jauh lebih panjang dan terurai dari satu atau dua paragraph. Dalam menulis sebuah esai, sistematik yang umum dipraktekkan adalah : (1) pendahuluan, (2) isi atau body, dan (3) penutup.

Meskipun menulis esai memiliki kesamaan dengan menulis paragraf, namun seorang penulis esai harus memiliki pengetahuan dan keterampilan yang dapat dimanfaatkan untuk memperkaya esai tersebut. Dalam hal ini, sebuah esai 
dapat ditulis dengan menerapkan jenisjenis teks yang berbeda, seperti deskripsi, narasi, ekspositori atau argumentasi. Namun demikian, pemilihan jenis-jenis teks dalam sebuah esai bergantung pada tujuan, kematangan dan tingkat kemampuan penulisan. Dalam konteks kegiatan menulis akademik di antara para guru, Langer (1992: 35) menjelaskan bahwa sebuah esai dilengkapi dengan struktur yang mencerminkan kematangan dan tingkat kemampuan sebagai berikut. Pertama, Description - a variety of types of subordinate elaborations, including manner, attribution, specific, equivalent, setting, identification, epilogue. Kedua, Evaluation - opinion or commentary about ideas or events found elsewhere in the text. Ketiga, Evidence - supporting argument. Keempat, Explanation - causal antecedents subordinate in staging to the main idea or event being explained (require explicit causal marker). Kelima, Adversative - comparison between alternatives, where one is less favored and subordinate; the dominant alternative is related to a higher node.

Dalam analisis tulisan akademik, sebuah teks juga perlu dievaluasi dan dipahami secara konvensional dan normatif, yakni kepatuhan penulis terhadap kaidahkaidah yang berlaku dalam suatu bahasa. Dalam hal ini, kaidah-kaidah akademik dan bahasa Indonesia menjadi rujukan dalam menulis sebuah karya tulis akademik. Idealnya, sebuah esai akademik juga harus memperlihatkan dan mempertegas keterkaitan antara teks dan konteks. Lebih dari itu, apapun jenis teks yang ditulis oleh seorang penulis, sebuah teks akademik harus memperlihatkan kohesi dan koherensi yang ditunjukkan dalam paragraf-paragraf yang membangunnya. Koherensi yang dimaksud di sini adalah "your paragraph is eassy to read and understand because (1) your supporting sentences are in some kind of logical order and (2) your ideas are connected by the use of appropriate transition signals (Oshima \& Hogue, 1998: 18). Dengan demikian, esai yang baik akan terlihat dari urutan logika dan penggunaan markahmarkah transisi yang tersurat dalam setiap paragrafnya.

Dalam penelitian ini, sebanyak 126 guru non-bahasa pada jenjang Sekolah Menengah Pertama dan Sekolah Menengah Atas telah berpartisipasi dalam penelitian ini dan tulisan akademik mereka yang berupa esai telah dijadikan sampel untuk mengetahui tingkat kemampuan menulis akademik mereka. Secara umum, data tentang kemampuan menulis mereka dapat dilihat pada Tabel 3 di bawah ini. Tabel 3 menunjukkan bahwa secara keseluruhan, skor rata-rata tulisan akademik yang dicapai oleh para guru adalah 57,2 dari skor total 100.

Komponen pertama yang dinilai adalah content dan berkaitan dengan pengembangan gagasan dan thesis statement menurut pendapat pribadi, fakta, ilustrasi

Tabel 3. Skor Rata-Rata Kemampuan Menulis Akademik

\begin{tabular}{ccccccc}
\hline Content & $\begin{array}{c}\text { Organi- } \\
\text { zation }\end{array}$ & Discourse & Syntax & Vocabulary & Mechanics & Skor rata-rata \\
\hline 15,5 & 10,8 & 9,1 & 9,6 & 8,0 & 7,8 & 57,2 \\
\hline
\end{tabular}

Tabel 4. Skala Penilaian Komponen Content (Skor total 24)

\begin{tabular}{lcccc}
\hline $\begin{array}{l}\text { Rentang/ } \\
\text { Kategori }\end{array}$ & $\begin{array}{c}\mathbf{2 0 - 2 4} \\
\text { (Sangat Baik) }\end{array}$ & $\begin{array}{c}\mathbf{1 5 - 1 9} \\
\text { (Baik) }\end{array}$ & $\begin{array}{c}\mathbf{1 0 - 1 4} \\
\text { (Cukup) }\end{array}$ & $\begin{array}{c}5-9 \\
\text { (Kurang) }\end{array}$ \\
\hline Persentase & 24 orang (19\%) & 50 orang (39\%) & 41 orang $(32,5 \%)$ & orang $(8,5 \%)$ \\
\hline
\end{tabular}


ataut perbandingan (Brown, 2007). Pada komponen content ini, skor tertinggi yang dicapai adalah 23, sedangkan skor terendah adalah 7. Sebagaimana disebutkan di atas, skor rata-rata yang dapai dicapai oleh para guru adalah 15,5 dari skor total 24. Selain itu, berdasarkan data yang dimuat dalam Tabel 4, tampak bahwa hanya ada 24 orang (19\%) dari 126 guru yang mampu mengembangkan komponen content dengan sangat baik. Sebanyak 50 orang (39\%) mampu mencapai skor dengan kategori baik. Para guru lainnya belum mampu menunjukkan kemampuan yang memadai dalam komponen ini, yaitu 41 orang $(32,5 \%)$ termasuk dalam kategori cukup dan 11 orang $(8,5 \%)$ dalam kategori kurang.

Komponen berikutnya adalah organization, yaitu komponen yang berhubungan dengan bagaimana penulis mengantarkan tulisan secara efektif pada bagian pendahuluan, merangkai gagasan-gagasan dalam urutan logis dan menarik kesimpulan (Brown, 2007). Sebagaimana terlihat dalam Tabel 5, hasil pengukuran penguasan komponen ini menunjukkan bahwa tidak ada seorangpun yang mempunyai kemampuan yang sangat baik dalam mengembangkan komponen organisasi. Sebagian besar dari mereka, atau 100 orang $(79,3 \%)$ hanya memiliki kemampuan dalam kategori cukup, sedangkan 15 orang (12,2\%) memiliki kemampuan yang baik dan 11 orang (8,5\%) kurang memiliki kemampuan dalam mengem- bangkan tulisan akademik pada aspek organisasi ini. Hasil pengolahan data menunjukkan bahwa skor tertinggi pada komponen ini adalah 12, sedangkan skor terendah adalah 5, dengan skor rata-rata hanya mencapai 10,8.

Sementara itu, komponen ketiga yang dinilai adalah discourse, yaitu bagaimana penulis mengembangkan paragraf dengan memperhatikan kohesi dan koherensi, kaidah-kaidah penulisan dan penggunaan rujukan (Brown, 2007). Data tentang komponen discourse menunjukkan bahwa tidak ada guru yang mempunyai kemampuan sangat baik dalam mengembangkan komponen ini, namun ada 24 orang guru (19\%) yang mempunyai kemampuan dalam kategori baik. Selebihnya hanya memiliki kemampuan dalam kategori cukup (78 orang atau 62\%) dan kategori kurang (24 orang atau 19\%). Sementara itu, nilai tertinggi dalam komponen ini adalah 13 dan nilai paling rendah adalah 5. Secara keseluruhan, para guru dapat mencapai skor rata-rata 9,1 dari skor total 20 dalam komponen discourse ini, sebagaimana terlihat pada Tabel 6 .

Berbeda dengan ketiga komponen di atas, komponen syntax atau komponen yang berkaitan dengan efektivitas kalimat diukur hingga skor total 12 pada interval empat, sebagaimana dapat dilihat pada tabel di bawah ini. Tabel 7 memperlihatkan bahwa sebagian besar sampel (91 orang atau $72 \%$ ) mampu mengembangkan komponen ini dengan baik, dan 35 orang

Tabel 5. Skala Penilaian Komponen Organization (Skor total 20)

\begin{tabular}{lcccc}
\hline $\begin{array}{l}\text { Rentang/ } \\
\text { Kategori }\end{array}$ & $\begin{array}{c}\mathbf{1 6 - 2 0} \\
\text { (Sangat Baik) }\end{array}$ & $\begin{array}{c}\mathbf{1 1 - 1 5} \\
\text { (Baik) }\end{array}$ & $\begin{array}{c}\mathbf{6 - 1 0} \\
\text { (Cukup) }\end{array}$ & $\begin{array}{c}\mathbf{1 - 5} \\
\text { (Kurang) }\end{array}$ \\
\hline Persentase & 0 & 15 orang $(12,2 \%)$ & 100 orang $(79,3 \%)$ & 11 orang $(8,5 \%)$ \\
\hline
\end{tabular}

Tabel 6 Skala Penilaian Komponen Discourse (Skor total 20)

\begin{tabular}{lcccc}
\hline $\begin{array}{l}\text { Rentang/ } \\
\text { Kategori }\end{array}$ & $\begin{array}{c}\mathbf{1 6 - 2 0} \\
\text { (Sangat Baik) }\end{array}$ & $\begin{array}{c}\mathbf{1 1 - 1 5} \\
\text { (Baik) }\end{array}$ & $\begin{array}{c}\mathbf{6 - 1 0} \\
\text { (Cukup) }\end{array}$ & $\begin{array}{c}\mathbf{1 - 5} \\
\text { (Kurang) }\end{array}$ \\
\hline Persentase & 0 & 24 orang (19\%) & 78 orang (62\%) & 24 orang (19\%) \\
\hline
\end{tabular}


(28\%) masuk ke dalam kategori cukup. Dari 126 orang guru yang menjadi sampel penelitian ini, tidak ada seorangpun yang masuk ke dalam kategori sangat baik dan kurang, sehingga data hanya terdistribusi dalam kategori baik dan cukup.

Dalam komponen kosakata (vocabulary) data tampak terdistribusi secara merata dalam kategori sangat baik, baik dan cukup. Tidak ada seorangpun yang masuk ke dalam kategori kurang, sebagaimana dapat dilihat pada Tabel 8 . Berdasarkan hasil pengolahan data, 33 orang $(26 \%)$ masuk ke dalam kategori sangat baik, 44 orang (35\%) dalam kategori baik, dan 49 orang (39\%) dalam kategori cukup. Skor rata-rata untuk komponen ini adalah 8,0 dari skor total 12 , dengan nilai tertinggi 11 dan nilai terendah 5. Data ini sekaligus menunjukkan bahwa para guru yang terlibat dalam penelitian ini telah menguasai kosakata yang cukup untuk menulis karya-karya akademik, namun banyak di antara mereka yang belum dapat dikategorikan sebagai penulis yang kaya dengan kosakata.

Komponen terakhir adalah mecanics, yaitu komponen yang menunjukkan kemampuan dalam menggunakan ejaan, tanda baca, dan kutipan (Brown, 2007). Seperti halnya data komponen kosakata, data tentang komponen mechanics hanya terdistribusi pada kategori sangat baik, baik dan cukup, namun tidak merata karena sebagian besar sampel terkonsentrasi dalam kategori baik (76 orang atau 64\%). Tabel 9 menunjukkan bahwa tidak ada guru yang masuk ke dalam kategori kurang. Sementara itu, mereka yang masuk ke dalam kategori baik adalah sebanyak 27 orang $(21,4 \%)$ dan kategori cukup sebanyak 23 orang $(18,2 \%)$. Berdasarkan data tentang penguasaan komponen ini, lebih dari 50\% guru masih melakukan sejumlah kesalahan dalam ejaan, tanda baca dan kutipan. Gejala ini diduga karena mereka tidak terbiasa menulis untuk keperluan akademik. Dengan kata lain, pengetahuan mereka tentang mecanicskurang memadai karena mereka tidak sering menulis.

\section{Beberapa Kesalahan Umum dalam Tu- lisan Akademik Guru}

Sebagaimana diuraikan di atas, hasil tulisan akademik guru dinilai dengan menggunakan instrumen yang mengukur enam komponen atau kategori: content, organization, discourse, syntax, vocabulary dan mechanics.Untuk mengidentifikasi kesalahan-kesalahan umum yang dilakukan oleh para guru dalam menulis karya

Tabel 7. Skala Penilaian Komponen Syntax (Skor total 12)

\begin{tabular}{lcccc}
\hline $\begin{array}{l}\text { Rentang/ } \\
\text { Kategori }\end{array}$ & $\begin{array}{c}\mathbf{1 0 - 1 2} \\
\text { (Sangat Baik) }\end{array}$ & $\begin{array}{c}\text { 7-9 } \\
\text { (Baik) }\end{array}$ & $\begin{array}{c}\text { 4-6 } \\
\text { (Cukup) }\end{array}$ & $\begin{array}{c}\mathbf{1 - 3} \\
\text { (Kurang) }\end{array}$ \\
\hline Persentase & 0 & 91 orang (72\%) & 35 orang (28\%) & 0 \\
\hline
\end{tabular}

Tabel 8 Skala Penilaian Komponen Vocabulary (Skor total 12)

\begin{tabular}{lcccc}
\hline $\begin{array}{l}\text { Rentang/ } \\
\text { Kategori }\end{array}$ & $\begin{array}{c}\mathbf{1 0 - 1 2} \\
\text { (Sangat Baik) }\end{array}$ & $\begin{array}{c}\text { 7-9 } \\
\text { (Baik) }\end{array}$ & $\begin{array}{c}\text { 4-6 } \\
\text { (Cukup) }\end{array}$ & $\begin{array}{c}\text { 1-3 } \\
\text { (Kurang) }\end{array}$ \\
\hline Persentase & 33 orang (26\%) & 44 orang (35\%) & 49 orang (39\%) & 0 \\
\hline
\end{tabular}

Tabel 9. Skala Penilaian Komponen Mechanics (Skor total 12)

\begin{tabular}{lcccc}
\hline $\begin{array}{l}\text { Rentang/ } \\
\text { Kategori }\end{array}$ & $\begin{array}{c}\mathbf{1 0 - 1 2} \\
\text { (Sangat Baik) }\end{array}$ & $\begin{array}{c}7-9 \\
\text { (Baik) }\end{array}$ & $\begin{array}{c}\text { 4-6 } \\
\text { (Cukup) }\end{array}$ & $\begin{array}{c}\text { 1-3 } \\
\text { (Kurang) }\end{array}$ \\
\hline Persentase & 27 orang (21,4\%) & 76 orang $(60,4 \%)$ & 23 orang $(18,2 \%)$ & 0 \\
\hline
\end{tabular}


akademik, maka keenam komponen tersebut menjadi rujukan. Dalam komponen pertama, kesalahan dapat ditemukan dengan mudah dalam pengembangan gagasan dan thesis statement. Kesalahan hal ini juga dapat dikategorikan sebagai kelemahan atau ketidamampuan guru dalam mengembangkan gagasan dan thesis statement karena sebagian besar guru belum mampu menulis paragraph dengan mengungkapkan gagasan-gagasan menurut pendapat pribadi, fakta, ilustrasi atau perbandingan sebagaimana seharusnya sebuah paragraf yang baik. Kesalahan kedua masih berkaitan dengan kesalahan pertama. Dalam hal ini, para guru tidak menunjukkan kemampuan dalam merangkai paragraf. Kesalahan ini dapat diidentifikasi dalam komponen organization. Bahkan kesalahan ini tampak lebih jelas apabila kita menelusuri seluruh rangkaian tulisan dari bagian pendahuluan hingga kesimpulan. Hasil analisis menunjukkan bahwa hampir tidak ada tulisan efektif yang menggambarkan komponen-komponen organization yang baik.

Dalam komponen discourse, kelemahan-kelemahan dapat ditemukan dalam kohesi dan koherensi antar paragraf, kepatuhan terhadap kaidah-kaidah penulisan dan penggunaan rujukan. Mungkin dapat dimaklumi bahwa pada saat tes esai ini dilakukan, para guru tidak menyiapkan berbagai bahan rujukan yang diperlukan untuk menulis sebuah esai. Di lain pihak, mereka tidak mampu menunjukkan pengetahuan tentang bagaimana kaidah-kaidah penulisan harus diterapkan. Dalam situasi apapun, kemampuan menulis harus disertai dengan pengetahuan tentang kaidah-kaidah ini. Kesalahan-kesalahan hampir tidak ditemukan dalam komponen syntax atau tatakalimat, terutama karena para guru hanya menulis kalimat-kalimat sederhana. Namun demikian, sebagian dari mereka tidak menunjukkan kemampuan yang memadai dalam memilih dan menggunakan ko- sakata yang sesuai untuk tulisan akademik dan kematangan mereka sebagai penulis dewasa. Dengan kata lain, mereka tidak kaya dengan kosakata sehingga tidak dapat dipungkiri bahwa mereka mengalami kesulitan dalam mengembangkan gagasan-gagasan. Terakhir, berdasarkan data hasil analisis terhadap penguasaan komponen mechanics, sebagian besar guru masih membuat kesalahan-kesalahan yang berkaitan dengan ejaan, tanda baca dan kutipan. Kesalahan ejaan seringkali berhubungan dengan penggunaan imbuhan, sedangkan kesalahan tanda baca dapat dilihat dalam penggunaan huruf besar atau kecil di awal kalimat, titik, koma dan tanda baca lain.

\section{Penyebab Kesulitan dalam Menulis Akademik}

Pada kenyataannya, kegiatan menulis akademik bukan merupakan satu tugas mudah bagi sebagian besar guru. Oleh karena itu, tidaklah mengherankan jika sebagian besar guru yang terlibat dalam penelitian ini mengalami kesulitan dalam menulis akademik. Data angket menunjukkan bahwa seluruh guru yang terlibat dalam penelitian ini mengakui bahwa mereka pernah menulis skripsi sebagai persyaratan untuk menyelesaikan studi pada jenjang strata sarjana (S1). Dari 126 guru, hanya 25 guru yang memiliki pengalaman lain dalam menulis karya tulis ilmiah dalam bentuk diktat bahan ajar dan makalah. Pengalaman inipun sangat terbatas karena mereka menulis pada kesempatan tertentu saja. Namun demikian, pada umumnya para guru menyadari bahwa kegiatan menulis akademik itu penting. Selain itu, merekapun memahami bahwa ketika kita menulis, kita menciptakan makna dan menggabungkan berbagai gagasan dan fakta ke dalam sesuatu yang baru. Bahkan kegiatan menulis berkontribusi terhadap perkembangan pribadi seseorang. Ketika menulis, kita menjadi pemikir dan pembelajar yang 
aktif dan akhirnya mampu memahami diri kita melalui pencatatan, penjelasan dan pemaparan pengamalan serta pikiran kita. Selain itu, menulis juga membantu kita berhubungan atau berkomunikasi dengan orang lain. Dorongan untuk menulis bisa sama pentingnya dengan kebutuhan untuk berbincang dengan orang lain atau menjawab komentar dalam diskusi kelas. Kadang-kadang kita mengharapkan para pembaca mengetahui apa yang kita ketahui; kita ingin berbagi sesuatu dengan mereka. Bahkan lebih dari itu, kita ingin mempengaruhi perilaku atau keyakinan pembaca lewat tulisan kita. Dengan kata lain, kita ingin berkomunikasi dengan orang lain lewat berbagai cara dan tujuan.

Dalam konteks situasi yang ditemukan dalam penelitian ini, ada sebuah pernyataan menarik dalam sebuah buku yang ditulis oleh Axelrod dan Cooper (1988: 5), “We don't see writing as a communication of something already discovered, as 'thruths' already known. Rather, we see writing as a job of experiment. It's like any discovery job; you don't know what's going to happen until you try it." Proses menulis tidak bisa berlangsung secara otomatis karena ada beberapa aspek yang perlu dipertimbangkan. Menurut Hamberlandt (1997), menulis adalah sebuah proses yang melibatkan empat komponen penting, yaitu "planning, making meaning, expressing meaning, and reviewing the text" (hal. 345). Selanjutnya, kegiatan menulis yang kita kenal di dunia pendidikan adalah menulis yang bermakna dan bertujuan.Berbagai penelitian telah dilakukan untuk membuktikan pentingnya menulis untuk berbagai tujuan. Dalam proses belajar, menulis tidak dapat dipisahkan dari tujuan belajar siswa dan tujuan mengajar guru. Dalam konteks pembelajaran, Ellis, Taylor dan Drury (2005: 49) mengungkapkan bahwa "the experience of writing not only helps students to become familiar with the standards and style of written expression expected in their disciplines, but it also helps them to clarify their understanding of the subject matter about which they are writing."

Sementara itu, dalam konteks akademik, menulis untuk kepentingan akademik yang hasilnya berupa karya tulis ilmiah merupakan sebuah kebutuhan dan tuntutan yang tidak dapat dihindari dan diabaikan. Salah satu bentuk karya tulis ilmiah itu adalah artikel yang dapat diterbitkan dalam sebuah jurnal ilmiah. Artikel jurnal ilmiah bisa berbentuk artikel teoretis dan artikel penelitian. Kedua jenis artikel jurnal ini harus memenuhi syarat-syarat tertentu agar layak diterbitkan dalam sebuah jurnal ilmiah. Setiap jurnal ilmiah menentukan syarat-syarat kelayakan tertentu yang harus dipenuhi oleh penulis artikel. Pada umumnya, ada tiga aspek penting yang perlu diperhatikan dalam penulisan sebuah karya akademik: (1) struktur umum artikel, (2) kaidah-kaidah penulisan yang berlaku, dan (3) pengembangan gagasan dalam paragraf. Lebih lanjut, Murray (2008: 12) menyatakan bahwa dalam kegiatan menulis akademik, seorang penulis dituntut untuk "(1) mengetahui kaidah-kaidah akademik, (2) memahami kaidah-kaidah profesi, (3) memiliki pengetahuan tentang kaidah-kaidah lain yang relevan, dan (4) berpikir secara mandiri dan menguasai pokok bahasan yang ditulis."

Kemampuan menulis tidak dapat dikuasai secara otomatis tetapi harus dipelajari dan dikuasai secara bertahap. Dalam hal ini, menulis adalah sebuah proses, bukan sebuah produk. Menulis akademik merupakan sebuah proses yang harus dikuasai setelah seseorang mampu menulis dengan tujuan personal biasa. Kemampuan menulis akademik ini akan dapat dikuasai setelah seorang penulis mampu menguasai berbagai hal sebagaimana disebutkan di atas. Namun demikian, penguasan kemampuan menulis 
tidak bersifat independen. Artinya bahwa kemampuan menulis ini harus didukung oleh kegiatan berbahasa lain, terutama membaca. Menulis dan membaca adalah dua proses yang berbeda, tetapi memiliki medium yang sama, yaitu bahasa tulis. Dalam hal ini, Langer (1992:33) berpendapat bahwa "the structures and strategies that readers and writers use to organize, remember, and present messages are generally the same in reading and writing. They are mostly different in purpose they serve." Dalam hal ini dapat diasumsikan bahwa kegiatan membaca dan menulis pada umumnya hanya berbeda dalam tujuan, namun hal yang lebih penting lagi adalah pengalaman dalam mengembangkan kedua keterampilan berbahasa tersebut.

Sekali lagi, menulis itu penting tetapi sulit, terutama menulis akademik. Menulis tidak hanya berkaitan dengan penulis itu sendiri, tetapi juga melibatkan pembaca. Ketika menulis, seorang penulis harus berpikir tentang siapa yang akan membaca tulisannya. Dari sudut pandangan pembaca ini, seorang penulis akan menjumpai beberapa karakteristik bahasa tulis. Menurut Brown (2007: 397-398), ada beberapa karakteristik bahasa tulis yang perlu diperhatikan: (1) permanence, (2) production time, (3) distance, (4) orthography, (5) complexity, (6) vocabulary, dan (7) formality. Menulis tidak seperti berbicara atau membaca. Begitu tulisan dibaca oleh para pembaca, sepertinya sulit untuk melakukan perbaikan otomatis apabila ditemukan kesalahan-kesalahan. Oleh karena itu, seorang penulis memerlukan orang lain untuk membaca tulisannya. Menulis juga berkaitan dengan waktu. Apabila seorang penulis memiliki banyak waktu, ia dapat mengembangkan berbagai gagasan dalam tulisannya dengan leluasa. Tetapi apabila ia hanya memiliki sedikit waktu, maka ia akan mengalami kesulitan untuk menghasilkan tulisan yang baik. Dalam hal ini, praktek dan latihan sangat diperlukan. Selanjutnya, karena ada jarak antara penulis dan pembaca, maka si penulis harus memahami pandangan pembaca dari berbagai aspek seperti kosakata, kalimat atau paragraf. Dalam setiap bahasa, termasuk bahasa Indonesia, penulis dituntut untuk menguasai kaidah-kaidah penulisan, sistem semantik, ejaan, sintaksis, morofologis dan lain-lain. Dalam bahasa Indonesia pada khususnya, kompleksitas menulis seringkali dijumpai karena bahasa Indonesia sangat dipenmgaruhi oleh berbagai bahasa daerah. Oleh karena itu, tidaklah mengherankan jika dalam beberapa hal, menulis dalam bahasa Indonesia bisa rumit dan kompleks.

Untuk mengurangi kerumitan dan kompleksitas menulis akademik, pelatihan sangat penting bagi para guru. Data penelitian ini menunjukkan bahwa dari 126 guru, sebanyak 75 guru pernah mengikuti pelatihan menulis akademik yang diselenggarakan oleh pihak kementerian pendidikan dan kebudayaan di tingkat daerah. Dari 75 guru, ada 44 guru yang telah mengikuti pelatihan sebanyak dua kali atau lebih. Sementara itu, sebanyak 51 guru belum pernah mengikuti pelatihan menulis akademik, kecualia kegiatan menulis karya ilmiah selama mereka mengikuti Pendidikan dan Latihan Profesi Guru (PLPG). Pada umumnya mereka mengharapkan pelatihan untuk meningkatkan kemampuan menulis, terutama untuk kepentingan promosi atau kenaikan pangkat. Melihat fenomena, kegiatan menulis akademik di antara para guru masih dipengaruhi dan didorong oleh tujuan-tujuan formal. Oleh karena itu, tidaklah mengherankan jika menulis akademik tidak muncul dari inisiatif pribadi untuk memperkokoh bidang keilmuan dan akademik di sekolah. Dengan kata lain, kegiatan menulis akademik belum menjadi satu kebutuhan penting bagi para guru untuk mendorong tumbuh suburnya pola pikir akademik yang baik. 
Sesuai dengan namanya, menulis akademik adalah satu kegiatan menulis yang dilakukan untuk tujuan-tujuan akademik tertentu. Dalam menulis akademik, kegiatan menulis bersifat formal atau sangat formal karena penulis dituntut untuk mengikuti kaidah-kaidah yang kompleks, terutama tentang bagaimana memaparkan, menjelaskan, membandingkan, mengilustrasikan, mempertahankan, mengkritik dan berargumen. Ketika menulis sebuah karya akademik, seorang penulis tentunya harus terlebih dahulu menetapkan tujuan yang hendak dicapai dan sasaran pembaca yang ingin dijangkau. Semua ini membuat kegiatan menulis akademik semakin sulit.Namun demikian, ciri-ciri tulisan akademik mudah diidentifikasi karena tulisan akademik harus memuat informasi spesifik yang jelas dan memenuhi kaidah-kaidah disiplin ilmu yang diuraikan. Salah satu ciri penting dari sebuah tulisan akademik adalah register atau aspek-aspek bahasa yang berkaitan dengan konteks. Menurut Coffin, dkk. (2003), register mencakup "formality, sentence structure, specialist terminology, dan personal voice." Dalam hal ini, tulisan akademik menekankan formalitas dan struktur kalimat formal, serta istilah-istilah teknis khusus dengan menghindari pendapat pribadi yang tidak didasarkan pada fakta, data atau kajian tertentu. Selanjutnya, Coffin, dkk. (2003) memaparkan ciri-ciri penting lain yang dapat dideteksi dalam sebuah tulisan akademik, yaitu (1) tingkat kepadatan leksikal yang tinggi, (2) penggunaan kata benda dan kata kerja yang padat, (3) konstruksi impersonal, dan (4) modifikasi pernyataan melalui penggunaan kata kerja dan frase. Secara lebih spesifik, Anderson dan Poole (1994: 6) mengatakan bahwa "scientific writing is not of a personal or conversational nature and for this reason the third person is commonly used. As a general rule, personal pronouns such as I, we, you, me, my, our and us should not appear except in quotations." Dengan demikian, penulis akademik harus menghindari bahasa atau pandangan pribadi.

Untuk menciptakan kebiasaan menulis akademik, sekolah harus menjadi tempat yang kondusif dan mendorong setiap guru untuk menulis untuk tujuan-tujuan akademik.Pandangan atau bahasa pribadi yang mampu mereka kembangkan harus merujuk kepada kajian-kajian ilmiah yang ada. Selanjutnya, agar tulisan akademik dapat dibaca oleh khalayak umum, maka diperlukan forum-forum tertentu untuk menyajikan tulisan akademik tersebut. Menurut sebagian besar guru (95\%) yang terlibat dalam penelitian ini, budaya akademik di sekolah belum tumbuh karena mereka selalu fokus pada kegiatan mengajar.Kegiatan-kegiatan seperti seminar, brainstorming, focus group discussion, atau penelitian masih merupakan kegiatan langka. Namun demikian, ada sekitar $5 \%$ guru yang pernah menampilkan tulisan akademik di sejumlah forum guru. Dalam penelitian yang dilakukan oleh Setiadi (2006 \& 2013), pada umumnya guru memiliki keyakinan bahwa mereka mampu melaksanakan tugas-tugas instruksional dengan baik terutama dalam mengajar, mengelola kelas dan menyiapkan berbagai perangkat pembelajaran. Namun demikian, dapat dimaklumi bahwa semua praktek akademik ini tidak berhubungan dengan langsung dengan kegiatan menulis akademik atau tidak menuntut mereka untuk menulis akademik sehingga dapat diperkirakan bahwa menulis akademik masih merupakan praktek langka di antara mereka.

\section{SIMPULAN}

Dengan merujuk kembali kepada teori tentang menulis esai yang dikemukakan oleh Langer (1992), ada beberapa hal perlu dicermati. Pertama, sebagian besar tulisan akademik yang ditulis oleh para guru yang menjadi sampel penelitian ini tidak menunjukkan karakteristik atau 
komponen penting dari sebuah esai, terutama komponen evaluasi. Dalam enam komponen yang dinilai, para guru masih menunjukkan sejumlah kesalahan dalam lima komponen, yaitu content, organization, discourse, vocabulary, dan mechanics. Kesalahan hampir tidak ditemukan dalam komponen syntax.

Selanjutnya, berdasarkan hasil penilaian dengan Skala Penilaian Kualitas Tulisan Akademik, sampel penelitian pada umumnya belum menunjukkan kemampuan menulis akademik yang memuaskan meskipun skor rata-rata tes menulis akademik tergolong ke dalam kategori "cukup baik". Berdasarkan hasil pengolahan data, skor terendah dan tertinggi adalah masing-masing 32 dan 70.Pada komponen content, skor rata-rata adalah 15,5 dari skor total 24 , organization 10,8 dari 20, discourse 9, 1 dari 20, syntax 9,6 dari 12 , vocabulary 8,0 dari 12 , dan mechanics 7,8 dari 12. Berdasarkan skor minimum dari setiap komponen, maka skor rata-rata terendah dicapai pada komponen content, sedangkan skor rata-rata tertinggi diraih pada komponen syntax.

Pada aspek content, para guru mampu mengembangkan gagasan-gagasan utama meskipun tidak selalu disertai dengan paparan, ilustrasi atau contoh, dan gagasan-gagasan pendukung. Di lain pihak, sejumlah sampel lain masih mengalami kesulitan dalam mengembangkan gagasan, terutama karena mereka kurang terampil dalam menghubungkan antara gagasan utama dan tema yang dibahas. Fokus merekapun tidak konsisten sehingga tulisan tidak memiliki koherensi atau kohesi antarparagraf. Dari sampel tulisan yang berhasil dikumpulkan, lebih dari $40 \%$ tidak menunjukkan kualitas komponen content yang memadai.Pada komponen organization, lebih dari 100 orang guru hanya mampu mencapai kategori cukup dan kurang. Kesulitan yang dihadapi tampak dalam merumuskan pernyataan-pernyataan dalam pendahu- luan dan urutan gagasan dalam paragraf. Mereka juga kurang mampu menarik kesimpulan-kesimpulan yang relevan dengan pernyataan-pernyataan yang dirumuskan.Kesulitan yang sangat menonjol dapat dilihat dalam menyusun paragraf karena setiap paragraf pada umumnya sangat pendek meskipun ukuran paragraf tidak ditentukan oleh ukuran panjang atau pendek paragraf tersebut. Penelitian ini membuktikan bahwa 78 orang $(62 \%)$ tidak memiliki kemampuan yang memadai dalam menggunakan unsur-unsur tertentu yang menandai peralihan antara satu paragraf dan paragraf lain.

Selain itu, pengalaman menulis merupakan salah satu faktor penting yang memberikan kontribusi besar terhadap kemampuan guru dalam menulis karya akademik. Apabila sebagian besar guru pernah menulis karya akademik dalam bentuk skripsi, maka dapat diasumsikan bahwa mereka tidak pernah atau jarang menulis karya akademik lain karena skripsi merupakan karya akademik puncak bagi mereka. Sebagian besar guru (80\%) menyatakan bahwa mereka menulis karya akademik untuk tujuan-tujuan selain keperluan promosi atau kenaikan pangkat, presentasi di forum ilmiah, keikutsertaan dalam sebuah lomba, keperluan publikasi ilmiah atau curah pendapat di sebuah media. Selain pengalaman, para guru memerlukan pelatihan karena pelatihan memiliki dampak positif dan sangat penting untuk menunjang pengembangan keterampilan menulis akademik, meskipun hanya sedikit guru yang pernah mengikuti pelatihan tersebut.

Terakhir, kegiatan menulis akademik tidak dapat dipisahkan dari budaya akademik yang tumbuh di lingkungan sekolah. Pada dasarnya, sekolah merupakan masyarakat akademik dimana para guru dapat mengembangkan kinerja dan kompetensi mereka melalui kegiatan penulisan karya akademik. 


\section{UCAPAN TERIMA KASIH}

Penelitian ini merupakan sebuah proses kerjasama di antara berbagai pihak. Dalam kesempatan ini, penulis ingin mengucapkan terima kasih kepada mereka yang telah memberikan kontribusi terhadap pelaksanaan penelitian dan pihakpihak yang membantu penerbitan hasil penelitian ini. Penelitian ini merupakan penelitian kelompok bersama dengan Prof. Drs. Chaedar Alwasilah, M.A., Ph.D. (almarhum). Ucapan terima kasih disampaikan kepada keluarga almarhum yang telah mengizinkan untuk mempublikasikan hasil penelitian ini. Ucapan terima kasih disampaikan kepada Direktur Sekolah Pascasarjana UPI yang telah memberikan bantuan finansial terhadap pelaksanaan penelitian. Terakhir, kami menghaturkan penghargaan yang sebesar-besarnya kepada para guru yang telah bersedia secara sukarela menjadi subjek penelitian ini.

\section{DAFTAR PUSTAKA}

Anderson, Jonathan \& Poole, Millicent. 1994. Thesis and Assignment Writing. $2^{\text {nd }}$ edition. Brisbane: John Wiley and Sons.

Axelrod, Rise B \& Cooper, Charles R. 1988. St. Martin's Writing Guide. New York: Heinemann.

Brown, Douglas H. 2007. Teaching by Principles. An Interactive Approach to Language Pedagogy. New York: Pearson Education.

Coffin, Caroline., Curry, Mary J., Goodman, Sharon., Hewings, Ann, Lillis, Theresa \& Swann,

Joan. 2003. Teaching Academic Writing: A Toolkit for Higher Education. New York: Routledge.
Departemen Pendidikan Nasional. 2008. Pedoman Sertifikasi Guru dalam Jabatan Melalui Penilaian Portofolio. Jakarta.

Ellis, RobertA., Taylor, Charlotte E. \& Drury, Helen. 2005. "Evaluating Writing Instruction Through an Investigation of Students' Experiences of Learning Through Writing". International Science 33: 49-71.

Hamberlandt, Karl. 1997. Cognitive Psychology. Second Edition. Boston: Allyn and Bacon.

Kementerian PAN dan RB. 2009.Peraturan Menteri PAN dan RB No. 16/2009 tentang Jabatan Fungsional Guru dan Angka Kreditnya. Jakarta.

Kementerian Pendidikan dan Kebudayaan. 2012. Kebijakan Pengembangan Profesi Guru: Materi Pendidikan dan Latihan Profesi Guru Tahun 2012. Jakarta.

Langer, JudithA. 1992. Reading, Writing, and Genre Development. Dalam Irwin, Judith.W \& Doyle, Mary A. (Eds). Reading/Writing Connections: Learning from Research. Newark, Delaware: International Reading Association.

Murray, Rowena. 2008. How to Write a Thesis. Second Edition. Berkshire, England: Open University Press.

Oshima, Alice. \& Hogue, Ann. 1998. Writing Academic English.Third Edition. New York: Longman.

Setiadi, Riswanda. 2006. Teacher' Self-efficacy and its Relation to Literacy Learning Outcomes of the Eight Grade Junior Secondary Students. Disertasi. Melbourne: Monash University.

Setiadi, Riswanda. 2013. "Korelasi antara Efikasi Diri dan Kinerja Guru Pascasertifikasi". Laporan penelitian tidak diterbitkan. Bandung: UPI. 